\title{
MANAJEMEN OPERASIONAL PAKET WISATA PERJALANAN INSENTIF DI PT. GOLDEN KRIS TOURS (Studi Kasus Rombongan Perusahaan Gunung Madu Lampung)
}

\author{
Nelsye Lumanauw \\ Email: nelsye.lumanauw@pib.ac.id \\ POLITEKNIK INTERNASIONAL BALI
}

\begin{abstract}
Reward company in each employee's performance is given in the forms of cash, goods, health facilities, or incentive trips. Incentive travel is not just an ordinary trip, but an extraordinary trip that is given as a reward for rewarding and recognizing the resources that excel. Implementation of incentive tour package at Golden Kris Tours is handled by the operations management department. Reservations with written confirmations from related parties, such as hotels, restaurants, tourist attractions, and technical preparation do not guarantee that management and implementation of the trip run without problems. This also happened to Gunung Madu Lampung group. Problems arise due to the lack of detailed technical preparation and coordination.

This research used a descriptive qualitative approach. Data were collected through in-depth interviews, observation, and documentation related to operations management, Golden Kris Tours tour packages, and then described to find the components of the problems occurring during the trip. The conclusion of this research is the implementation of operations management of incentive trips for the Gunung Madu Lampung group is going well, although accompanied by problems. Lack of coordination between the operational team in the office, group leader, and tour guide is the main cause of those problems.
\end{abstract}

Keywords: Operations Management, Tour Package, Incentive Trip/ Incentive Travel

\section{Abstrak}

Perjalanan insentif bukan hanya perjalanan biasa, tetapi perjalanan yang luar biasa yang diberikan sebagai reward untuk menghargai dan merekognisi sumber daya yang berprestasi. Pelaksanaan paket wisata perjalanan insentif pada biro perjalanan wisata Golden Kris Tours ditangani oleh bagian manajemen operasional. Pembukuan dengan konfirmasi tertulis dari pihak-pihak terkait, seperti hotel, restoran, atraksi wisata dan persiapan teknis yang matang tidak menjamin pengelolaan dan 
pelaksanaan di lapangan berjalan tanpa masalah. Hal ini juga terjadi pada rombongan Gunung Madu Lampung. Persiapan teknis yang tidak detail dan kurang koordinasi menjadi rumusan masalah. Tujuan penelitian ini untuk mendapatkan informasi terkait pelaksanaan manajemen operasional paket wisata perjalanan insentif di PT. Golden Kris Tours.

Penelitian ini menggunakan pendekatan deskriptif kualitatif. Data dikumpulkan melalui wawancara mendalam, observasi dan dokumentasi terkait manajemen operasional, paket wisata Golden Kris Tours, dan selanjutnya diuraikan untuk menemukan komponen permasalahan yang terjadi di lapangan. Kesimpulan pada penelitian ini adalah pelaksanaan manajemen operasional perjalanan insentif rombongan Gunung Madu Lampung secara keseluruhan berjalan baik, walaupun diiringi dengan permasalahan yang terjadi di lapangan. Kurangnya koordinasi antara tim operasional di kantor, ketua rombongan dan pemandu wisata di lapangan menjadi penyebab utama munculnya permasalahan tersebut.

Kata Kunci: Manajemen Operasional, Paket Wisata, Perjalanan Insentif

\section{Pendahuluan}

Setiap perusahaan dengan dukungan dari semua unsur berupaya memperoleh keuntungan maksimal. Sebagian keuntungan perusahaan diberikan kepada karyawan yang telah bekerja maksimal atas tercapainya tujuan perusahaan. Masing-masing perusahaan memiliki kriteria terhadap penilaian kinerja karyawan dan bentuk penghargaan. Penghargaan dalam setiap kinerja karyawan dapat diberikan dalam bentuk uang tunai, barang, fasilitas kesehatan, maupun perjalanan insentif. Perjalanan insentif menjadi salah satu upaya perusahaan dalam memberi motivasi atau penghargaan atas kinerja dan produktivitas karyawan.

Beberapa faktor dalam menentukan sukses perjalanan insentif sebagai bagian dari penyelenggaraan penghargaan karyawan perusahaan harus dikelola dengan sebaik-baiknya untuk memberikan kepuasan bagi karyawan peserta perjalanan sebagai orang berprestasi. Perjalanan insentif bukan hanya perjalanan biasa, tetapi perjalanan yang luar biasa yang diberikan sebagai reward untuk menghargai dan merekognisi sumber daya yang berprestasi. (Manurung, dkk, 2017:33) 
Biro perjalanan wisata (BPW) selaku organisasi penyediaan jasa wisata bertanggung jawab terhadap pengelolaan perjalanan insentif yang baik. Organisasi BPW terdiri dari beberapa unsur yang saling berkaitan demi tercapainya tujuan perusahaan dan kepuasan wisatawan yang ditangani. Bagian operasional atau manajemen operasional merupakan bagian yang langsung berkaitan dengan pelaksanaan paket wisata. Menurut Atmaja (2017:141), manajemen operasional menjadi komponen penting dalam perusahaan tour and travel. Menyajikan proses teknis operasional tour and travel belum banyak dilakukan oleh peneliti.

Manajemen operasional di BPW Golden Kris Tours dipimpin oleh seorang koordinator yang dibantu dua karyawan dalam pelaksanaan tugasnya. Masing-masing karyawan memiliki tugas yang berbeda dalam pekerjaan operasional, namun saling berkaitan dan berkomunikasi. Pemandu wisata dengan status kepegawaian free lancer dan sarana transportasi termasuk sopir, berada di bawah naungan bagian operasional. Data final terkait wisatawan dari bagian produk dipelajari dan diolah di bagian operasional untuk tahap pelaksanaannya. Demikian juga data rombongan dari Perusahaan Gunung Madu Lampung, proses awal pembukuan dilakukan bagian produk, selanjutnya tahap pelaksanaan oleh bagian operasional. Pembukuan dengan konfirmasi tertulis dari pihakpihak terkait, seperti hotel, restoran, atraksi wisata dan persiapan teknis yang matang tidak menjamin pengelolaan dan pelaksanaan di lapangan berjalan tanpa masalah. Hal ini juga terjadi pada rombongan perusahaan tersebut. Permasalahan muncul dikarenakan persiapan teknis yang tidak detail dan kurang koordinasi.

Bagaimana pelaksanaan manajemen operasional yang diterapkan oleh Perusahaan Golden Kris Tours, khususnya terhadap perjalanan insentif dari rombongan Perusahaan Gunung Madu Lampung merupakan tujuan dari penelitian ini. Adapun manfaat penelitian ini bagi Perusahaan 
Golden Kris Tours, yaitu evaluasi penerapan manajemen operasional terhadap perjalanan insentif yang menghasilkan masukan untuk penanganan paket wisata yang lebih baik.

\section{Tinjauan Pustaka}

Penggalian tinjauan pustaka diperoleh dari kajian pustaka, teori dan konsep terkait masalah yang diteliti dan menjadi landasan penelitian. Teori dan konsep yang digunakan meliputi manajemen operasional, paket wisata dan perjalanan insentif. Ketiganya menggambarkan pokok pikiran yang ingin disampaikan.

\subsection{Manajemen Operasional}

Manajemen operasional diartikan sebagai bagian dalam perusahaan dengan kegiatan mengelola berbagai proses, selanjutnya menciptakan dan memberikan layanan serta produk untuk memenuhi kebutuhan pelanggan organisasi (Robinson, et al., 2016:18). Parker (2018:1) menambahkan, bahwa manajemen operasional adalah pengaturan proses yang dirancang untuk mendistribusikan layanan.

Dalam melaksanakan produksi suatu perusahaan, diperlukan manajemen yang berguna untuk menerapkan keputusan-keputusan dalam upaya pengaturan dan pengoordinasian penggunaan sumber daya dari kegiatan produksi yang dikenal sebagai manajemen produksi atau manajemen operasi (Rusdiana, 2014:18).

\subsection{Paket Wisata}

Paket wisata adalah suatu perjalanan wisata satu atau beberapa tujuan kunjungan yang disusun dari berbagai fasilitas perjalanan tertentu dalam suatu acara perjalanan yang tetap, serta dijual sebagai harga tunggal yang menyangkut seluruh komponen dari perjalanan wisata (Utama, 
2014:37). Menurut Camilleri (2019:18) paket wisata merupakan wisata yang memasukkan semua layanan seperti, pengaturan layanan transpotasi dan akomodasi yang dipesan oleh wisatawan dalam satu harga. Adapun karakter paket wisata yaitu pengaturannya dilakukan terlebih dahulu, baik berupa kombinasi terhadap beberapa produk atau mencakup keseluruhan program yang lengkap.

\subsection{Perjalanan Insentif}

Peraturan Menteri Pariwisata Republik Indonesia Nomor 5 Tahun 2017 menyatakan bahwa perjalanan insentif adalah alat manajemen global yang menggunakan pengalaman wisata yang luar biasa untuk memotivasi dan/atau memberikan pengakuan kepada peserta dengan tujuan dapat meningkatkan kinerja dalam mendukung tujuan organisasi atau perusahaan. Tipe perjalanan insentif menurut Bhatia (2007), yaitu:

1. Perjalanan insentif terkait pekerjaan, yaitu ketika kinerja seseorang dianggap baik. Contohnya, terlibat dalam penyiapkan proyek baru, mengikuti pelatihan kepemimpinan merupakan bagian dari perjalanan tersebut.

2. Liburan terkait perjalanan insentif, yaitu ketika penghargaan yang diterima berupa liburan. Contohnya, bagian penjualan yang mencapai target atau melebihi target.

Berbagai regulasi yang diterbitkan pemerintah daerah terkait penyelenggaraan pemerintahan dan kepariwisataan dalam pengelolaan event MICE disuatu daerah untuk mengakomodir perihal yang terkait dengan kebijakan yang menguntungkan pada penerimaan pendapatan daerah dari penyelenggaraan dan pengelolaan event tertentu. (Manurung, dkk, 2017:36) 


\section{Metode Penelitian}

Lokasi penelitian di PT. Golden Kris Tours Bali, Jalan By Pass Ngurah Rai no. 7, Sanur, Denpasar. Perusahaan Golden Kris Tours merupakan biro perjalanan wisata bidang inbound berdiri sejak tahun 1972, dengan mayoritas pasar wisatawan Eropa, khususnya Perancis. Seiring dengan ketatnya persaingan, perusahaan berusaha melebarkan target pasar wisatawan free individual traveller (FIT) dan group incentif trip (GIT), baik domestik maupun internasional dengan tetap menjaga pasar yang sudah ada.

Teknik pengumpulan data pada penelitian ini adalah teknik observasi dengan pengamatan langsung terhadap pelaksanaan penanganan perjalanan insentif rombongan Gunung Madu Lampung. Beberapa instrumen yang digunakan berupa dokumen, pedoman wawancara dan kamera. Instrumen dokumen diantaranya mencakup penelitian-penelitian terdahulu, buku dan data perusahaan. Pedoman wawancara dalam penelitian ini adalah sejumlah pertanyaan tertulis, guna memperoleh data dari informan. Kamera diperlukan untuk mendokumentasikan pelaksanaan observasi sebagai penunjang penyajian data.

Jumlah sampel pada penelitian kualitatif tidak perlu besar, namun purposiveness (Anggito \& Setiawan, 2018:22). Penentuan informan pada penelitian ini, yaitu orang yang paham mengenai manajemen operasional perusahaan, yaitu koordinator operasional sebagai informan 1 dan ketua rombongan Gunung Madu Lampung sebagai informan 2. Adapun responden adalah karyawan perusahaan yang mengetahui tentang proses penanganan operasional paket wisata perjalanan insentif, yaitu karyawan di product department dan operation department. 


\section{Manajemen Operasional Paket Wisata Perjalanan Insentif}

Pembahasan terhadap manajemen operasional paket wisata perjalanan insentif mencakup tahapan: proses pembuatan, persiapan teknis dan pelaksanaan program. Masing-masing tahapan saling berkaitan dan berperan menentukan kesuksesan manajemen operasional paket wisata perjalanan insentif.

\subsection{Proses Pembuatan}

Proses pembuatan paket wisata perjalanan insentif diawali dengan komunikasi melalui email tanggal 29 Oktober 2019 oleh bagian produk Golden Kris Tours kepada Perusahaan Gunung Madu Lampung yang bergerak di bidang pengolahan tebu menjadi gula, dengan program sebagai berikut:

a. Hari 1: Ketibaan di bandara, penjemputan dan langsung diantar ke hotel.

b. Hari 2: Diberikan dua opsi yaitu berwisata atau melakukan pertemuan.

c. Hari 3: Kunjungan ke obyek-obyek wisata, makan malam di Pantai Jimbaran.

d. Hari 4: Acara bebas sampai waktu penjemputan ke bandara.

Setelah pengiriman proposal paket wisata tersebut, Golden Kris Tours tidak mendapat jawaban dari perusahaan di Lampung. Sehingga perusahaan menganggap proposal tidak disetujui atau disepakati.

Tanggal 7 Januari 2020, ketua personalia Perusahaan Gunung Madu Lampung melakukan komunikasi dengan product manager yang membawahi product department Golden Kris Tours, menginformasikan bahwa rombongan sebanyak 20 orang jadi ke Bali, dan meminta beberapa perubahan dalam paket wisata yang sudah dikirimkan. Rombongan yang direncanakan melakukan perjalanan insentif ke Bali tersebut merupakan peserta terpilih dari bagian sumber daya manusia (SDM) Perusahaan 
Gunung Madu Lampung. Selanjutnya terjadi komunikasi yang intens terkait perubahan-perubahan pada paket wisata. Kesepakatan paket wisatat yang kemudian disetujui dengan periode perjalanan sebagai berikut:

16 Januari 2020:

a. 16.00 : Ketibaan di bandara dengan pesawat GA 0422 pukul 16.00 dari Jakarta.

b. 16.30 : Menuju obyek wisata Garuda Wisnu Kencana (GWK).

c. 17.30 : Menuju Pantai Jimbaran untuk makan malam dan menikmati matahari terbenam.

d. 19.30 : Berangkat menuju Hotel The Sun Legian, tempat menginap selama di Bali.

e. 20.00 : Tiba di hotel, proses registrasi dan selanjutnya acara bebas atau jalan-jalan disekitar hotel.

17 Januari 2020:

a. 07.30 : Makan pagi di hotel.

b. 08.30 : Penjemputan untuk melakukan kunjungan ke obyek-obyek wisata.

c. 10.30 : TIba di Warung Rekreasi Bedugul (WRB) untuk melakukan kegiatan team building.

d. 13.00 : Makan siang disediakan di WRB.

e. 14.00 : Rombongan menuju obyek wisata Danau Bratan.

f. 15.00 : Perjalanan menuju Tanah Lot.

g. 17.00 : Tiba di Tanah Lot menikmati keindahan pemandangan pura di atas batu karang.

h. 18.30 : Rombongan menuju Restoran Wanaku untuk menikmati makan malam.

i. 21.00 : Rombongan kembali ke hotel untuk beristirahat.

18 Januari 2020:

a. 07.30 : Makan pagi di hotel.

b. 08.30 : Pemjemputan untuk melakukan kunjungan ke obyekobyek wisata.

c. 09.30 : Tiba di Tirta Empul Tampaksiring, tempat suci umat Hindu.

d. 10.30 : Berangkat menuju Kintamani menikmati pemandangan Gunung dan Danau Batur.

e. 12.00 : Makan siang di Restoran Amora Kintamani.

f. 13.00 : Rombongan menuju Ubud, mengunjungi hutan kera dan jalan-jalan di Pasar Ubud.

g. $\quad 18.00$ : Rombongan menuju Sanur untuk makan malam.

h. $\quad 19.00$ : Tiba di Restoran Natrabu untuk menikmati makan malam dengan menu masakan Padang.

i. 20.00 : Berangkat menuju hotel untuk istirahat. 
19 Januari 2020:

a. 07.00 : Makan pagi di hotel.

b. 08.00 : Penjemputan menuju bandara untuk penerbangan GA 0403 jam 09.40 ke Jakarta.

Tahap selanjutnya, karyawan reservasi yang juga bagian dari product department melakukan proses pembukuan ke Hotel Sun Island Legian, sebagai hotel yang direkomendasi oleh Golden Kris kepada Gunung Madu Lampung. Selain hotel, karyawan reservasi juga melakukan pembukuan ke GWK untuk mendapatkan harga khusus sesuai kontrak. Pembukuan terhadap seluruh restoran yang digunakan juga dilakukan berdasarkan kontrak yang telah disepakati. Setelah semua komponen tersebut mendapat konfirmasi, tahap akhir yang dilakukan adalah memasukkan data tersebut ke dalam sistem internal perusahaan, yaitu sistem kerucut. Operation department atau bagian operasional selaku bagian penanggungjawab pelaksanaan paket wisata, mempelajari data yang sudah dimasukkan ke dalam sistem dan akan menyiapkan kebutuhan rombongan.

\subsection{Persiapan Teknis}

Manajemen operasional perusahaan Golden Kris Tours terdiri dari tiga personil yang dipimpin oleh koordinator operasional. Ketiga personil saling berkoordinasi dalam mempelajari data paket wisata yang sudah dimasukkan ke dalam sistem kerucut. Pemahaman terhadap paket wisata sangat penting, agar tidak ada komponen yang terlewati demi kelancaran pelaksanaan perjalanan insentif tersebut. Tim operasional melakukan persiapan untuk pemandu wisata dan transportasi, sedangkan pembukuan hotel, restoran dan obyek wisata yang memiliki kontrak sudah dilakukan oleh bagian produk.

Langkah pertama yang dilakukan tim operasional adalah memilih pemandu wisata yang akan membawa rombongan. Syarat utama pemandu 
wisata yang dipakai oleh perusahaan adalah menjadi anggota asosiasi Himpunan Pramuwisata Indonesia (HPI), dengan demikian kemampuan dan keahlian memandu wisatawan sudah teruji. Adapun syarat lainnya adalah rekomendasi dari biro perjalanan wisata lain dan metaati aturan yang berlaku di perusahaan, termasuk menyetujui besarnya honor atau guide fee yang berlaku di perusahaan.

Walaupun rombongan merupakan wisatawan domestik dan berbahasa Indonesia, pemandu wisata yang dipilih berdasarkan penguasaan penanganan bukan hanya faktor bahasa. Misalnya, pemandu wisata yang sudah terbiasa membawa wisatawan Eropa, tidak bisa dengan mudah membawa wisatawan dari Asia. Hal ini dikarenakan budaya asal wisatawan yang berbeda-beda, termasuk minat terhadap obyek wisata yang dikunjungi. Bagian operasional memilih pemandu wisata untuk rombongan Lampung tetap melakukan pertimbangan yang maksimal. Bapak Ngurah Bayuda dipilih menjadi pemandu wisata untuk rombongan tersebut, dengan pertimbangan sudah terbiasa memandu wisatawan domestik di biro perjalanan wisata lain.

Langkah berikutnya adalah pengadaan transportasi. Perusahaan Golden Kris Tours memiliki sarana transportasi sendiri dan sudah dilengkapi dengan izin angkutan pariwisata. Berbagai tipe transportasi milik perusahaan adalah Avanza, APV untuk kategori wisatawan FIT dan Elf, Hi-Ace, Bis Pariwisata berkapasitas 28 seats untuk kategori wisatawan GIT. Penggunaan transportasi pada periode high season yaitu bulan Juli sampai Agustus dan akhir Desember sampai awal Januari, jumlah wisatawan yang ditangani perusahaan melonjak drastis dan kapasitas kendaraan tidak mampu menangani, sehingga diperlukan kerjasama dengan perusahaan transportasi lain. Periode low season yaitu pada bulanbulan di luar high season, perusahaan bisa memaksimalkan penggunaan mobil milik sendiri, termasuk untuk rombongan dari Lampung tersebut. 
Jumlah rombongan 20 orang, tim operasional menyediakan bis dengan kapasitas 28 seats dan mobil khusus bagasi penumpang. Tim operasional memastikan kendaraan yang dipakai tidak bermasalah baik teknis, kelengkapan kotak Pertolongan Pertama Pada Kecelakaan (P3K), air condition (AC), kebersihan dan sopir yang mengendarainya. Dengan demikian, sarana transportasi sudah siap untuk dipakai oleh rombongan.

Pada tahap persiapan teknis ini, manajemen operasional tidak dilaksanakan dengan maksimal. Tidak ada pertemuan khusus antara pemandu wisata, sopir yang akan bertugas dan bagian produk selaku pembuat program paket wisata perjalanan insentif. Koordinator bagian operasional memberikan instruksi kepada pemandu wisata ataupun sopir secara terpisah. Hal ini bisa mengakibatkan informasi yang diberikan berbeda atau diterima berbeda oleh pemandu wisata maupun sopir.

\subsection{Pelaksanaan Program}

Ketibaan rombongan Perusahaan Gunung Madu Lampung tanggal 16 Januari 2020 adalah sesuai jadwal dengan menggunakan pesawat transit dari Jakarta, GA 0422 pukul 16.00 di Bandara I Gustri Ngurah Rai Bali. Sebagai tanda selamat datang di Bali, rombongan diberi kalungan bunga oleh seorang gadis berbusana tradisional Bali yang pengaturannya sudah disiapkan oleh tim operasional sebelumnya. Turut serta menyambut rombongan adalah General Manager (GM) Golden Kris Tours, salah satu tim operasional dan pemandu wisata yang akan memandu rombongan selama melakukan perjalanan insentif di Bali. Dengan menggunakan bis pariwsata yang sudah disiapkan, rombongan didampingi pemandu wisata, berangkat menuju obyek wisata GWK, sedangkan GM dan tim operasional kembali ke kantor untuk terus memantau pelaksanaan perjalanan insentif tersebut. 
Tiba di GWK, pemandu wisata segera mendatangi loket tiket untuk mendapatkan tiket masuk. Namun petugas loket GWK menginformasikan, tidak ada pembukuan dari perusahaan Golden Kris Tours. Pemandu wisata seketika itu juga menelpon bagian operasion yang diterima oleh koordinator operasional, untuk menginformasikan hal tersebut. Koordinator operasional dengan segera menelephon karyawan bagian produk, namun tidak tersambungkan. Jawaban segera tidak diperoleh dari bagian operasional, pemandu wisata kemudian mengambil inisiatif dengan menggunakan nama perusahaan lain dari rekan sesama pemandu wisata yang dijumpai saat itu di lokasi. Keputusan tersebut harus segera diambil demi kenyamanan rombongan yang sudah cukup lama menunggu di pintu masuk. Selain itu, apabila masuk tanpa adanya catatan pembukuan sebelumnya, maka akan dikenakan harga publik, yaitu 50\% persen lebih mahal dari harga kontrak dengan perusahaan. Koordinator operasional menelusuri masalah tersebut dengan berkomunikasi pada bagian produk dan GWK. Selanjutnya, diketemukan penyebutan nama yang berbeda sebagai penyebab terjadinya masalah. Bagian produk membukukan Group Lampung dari Golden Kris Tours, sedangkan petugas loket menerima dan mencatat informasi dari bagian reservasi GWK adalah Group Lampung tanpa penyebutan Golden Kris.

Pantai Jimbaran merupakan obyek wisata selanjutnya setelah GWK. Di pantai ini rombongan menikmati makan malam dengan kaki menyentuh pasir, sambil menikmati keindahan matahari terbenam. Tidak ada kendala selama pelaksanaan makan malam, rombongan merasa senang dengan suasana Pantai Jimbaran yang penuh dengan kafe tempat penjualan makanan dengan menu seafood. Selesai makan malam, rombongan diantar ke hotel untuk proses check-in dan bermalam di Hotel The Sun Legian.

Keesokan harinya, tanggal 17 Januari 2020 sesuai jadwal, rombongan dijemput oleh pemandu wisata jam 08.30 menuju Bedugul 
untuk melakukan kegiatan team building di Warung Rekreasi Bedugul (WRB) dengan hamparan hijau, taman luas, suasana sejuk penuh tanaman seperti tampak pada Gambar 1. Tiba di WRB, terjadi kesalahpahaman antara ketua rombongan dan pegawai WRB. Ketua rombongan menduga tidak ada persiapan dari WRB untuk kegiatan team building, sementara itu pegawai WRB menunggu kesiapan seluruh peserta untuk berkumpul, dikarenakan sebagain besar peserta langsung berpencar untuk berphoto. Pemandu wisata tampak kurang cepat menanggapi situasi tersebut. Walaupun, pada akhirnya seluruh peserta berkumpul untuk mengikuti kegiatan, namun pemandu wisata seharusnya bisa menginformasikan teknis pelaksanaan saat masih di dalam bis. Pada akhirnya, semua permainan dalam kegiatan team building terlaksana dengan baik. Seluruh peserta antusias pada setiap permainan yang diadakan. Berikut dokumentasi yang menggambarkan kekompakan peserta saat melakukan kegiatan team building, Gambar 2.

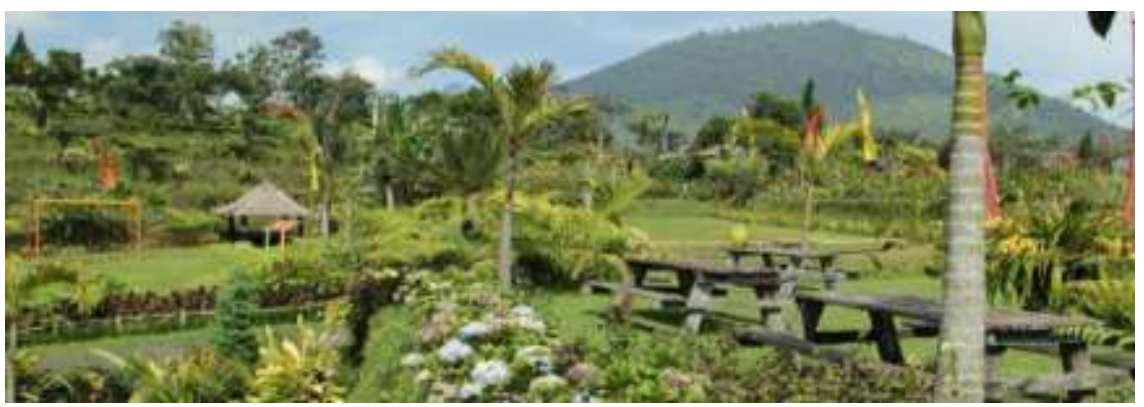

Gambar 1. Warung Rekreasi Bedugul

Sumber: www.warungrekreasibedugul.com

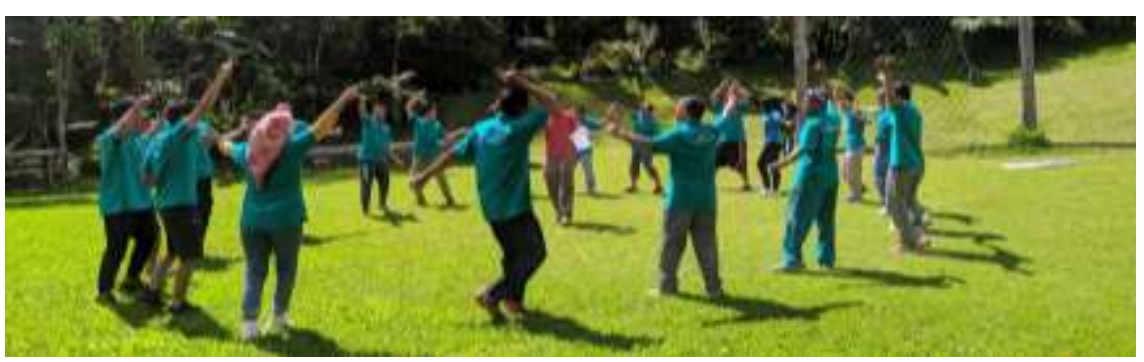

Gambar 2. Kegiatan Team Building Rombongan Gunung Madu Lampung Sumber: Hasil Observasi Peneliti 2020 
Setelah kegiatan team building berakhir, rombongan tidak langsung makan siang tetapi minta waktu untuk melakukan sholat di masjid terdekat. Lokasi masjid tidak jauh dari WRB, maka seluruh peserta jalan kaki menuju masjid tersebut. Makan siang prasmanan disantap oleh rombongan selesai melakukan sholat. Program berikutnya mengunjungi Danau Bratan dan Tanah Lot serta makan malam di Restoran Wanaku berjalan lancar sesuai jadwal, hingga rombongan tiba di hotel untuk beristirahat.

Tanggal 18 Januari 2020 terjadi perubahan program atas permintaan ketua rombongan. Tidak semua obyek wisata dalam paket wisata yang sudah ditetapkan dikunjungi, karena ketua rombongan menginginkan tiba di Kota Denpasar lebih awal untuk membeli oleh-oleh. Sesuai kesepakatan, hutan kera dan pasar Ubud batal dikunjungi. Rencana makan malam di Restoran Natrabu juga dirubah menjadi Bebek Tepi Sawah di Ubud dan menjadi lebih awal yaitu jam 05.00 sore. Perubahan program tersebut segera diinformasikan oleh pemandu wisata kepada tim operasional, yang kemudian menginformasikan kepada bagian produk. Selanjutnya, bagian produk menindaklanjuti pembatalan pembukuan di Restoran Natrabu untuk menghindari dikenakannya cancellation fee. Pembukuan makan malam di Bebek Tepi Sawah juga dilakukan segera, mengingat rombongan sudah dalam perjalanan menuju ke restoran tersebut. Makan malam yang dilakukan sore hari berjalan lancar dan rombongan menikmati hidangan khas bebek garing yang merupakan ciri khas Ubud. Sesampainya di Kota Denpasar, rombongan diantar menuju toko oleh-oleh Pia Enaak di Jalan By Pass Ngurah Rai Sanur. Waktu sisa yang tersedia pada hari ini dimanfaatkan oleh peserta mengunjungi Pantai Kuta, sebagai destinasi terakhir sebelum besok pulang ke Lampung melalui Jakarta. 
Hari terakhir, tanggal 19 Januari 2020 selesai makan pagi jam 08.00, sesuai jadwal pemandu wisata sudah menunggu di lobi hotel untuk menjemput rombongan berangkat ke bandara. Hari terakhir ini berjalan sesuai dengan jadwal yang sudah ditentukan. Permasalahan terjadi pada tahap pelaksanaan program akibat kurang koordinasi dalam pelaksanaan manajemen operasional paket wisata perjalanan insentif terhadap rombongan dari Gunung Madu Lampung. Koordinasi bagian operasional di kantor dan tim di lapangan serta ketua rombongan tidak terjalin lancar, dikarenakan perubahan mendadak yang diinginkan rombongan.

\section{Simpulan dan Saran}

\subsection{Simpulan}

Manajemen operasional pada tahap persiapan teknis tidak dilaksanakan dengan maksimal. Tidak ada pertemuan khusus antara pemandu wisata, sopir yang akan bertugas dan bagian produk selaku pembuat program paket wisata perjalanan insentif. Persiapan teknis yang tidak maksimal tersebut mengakibatkan munculnya permasalahan pada tahap pelaksanaan program. Koordinasi bagian operasional di kantor dan tim di lapangan serta ketua rombongan tidak terjalin lancar, dikarenakan perubahan mendadak yang diinginkan rombongan.

\subsection{Saran}

Tim operasional Golden Kris Tours sebaiknya melakukan rekonfirmasi terhadap seluruh komponen yang sudah dibukukan oleh bagian produk, untuk pelaksanaan teknis di lapangan yang akan dilakukan pemandu wisata. Koordinasi awal secara detail oleh tim operasional terhadap pemandu wisata penting dilakukan sebelum pelaksanaan paket wisata. Evaluasi post-trip harus dilakukan demi pemahaman setiap permasalahan yang terjadi dan pencegahannnya, serta mempertahankan pelaksanaan teknis yang sudah baik. 


\section{Daftar Pustaka}

Anggito, Albi dan Johan Setiawan. 2018. Metodologi Penelitian Kualitatif. Jawa Barat: CV. Jejak.

Atmaja, Edwin Hastawi. 2017. Manajemen Operasional Paket Wisata City Tour Surakarta di PT. Kirana Surya Gemilang Yogyakarta (Studi Kasus Rombongan Ikatan Wanita Bank Yogyakarta. Jurnal PariwisataTerapan, Vol.1, No. 2, 2017.

Bhatia, A.K. 2007. The Business of Tourism, Concept and Strategies. New Delhi: Sterling Publishers Private Limited.

Camilleri, Mark Anthony. 2019. Tourism Planning and Destination Marketing. UK: Emerald Publishing Limited.

Manurung, John Sihar, Rismawati, Pantas Simanjuntak. 2017. Pengaruh FaktorFaktor Perjalanan Insentif Terhadap Motivasi Dan Kinerja Sumber Daya Manusia Pada Perusahaan Asuransi Di Kota Medan. Article in Human Resource Management August 2017. ResearchGate.

Parker, David W. 2018. Service Operations Management. Second Edition. The Total Experience. UK: Edward Elgar Publishing Limited.

Peraturan Menteri Pariwisata Republik Indonesia Nomor 5 Tahun 2017 Tentang Pedoman Destinasi Penyelenggaraan Pertemuan, Perjalanan Insentif, Konvensi Dan Pameran.

Robinson, Peter, et al. Operations Management in the Travel Industry. $2^{\text {nd }}$ Edition. London: CAB International.

Rusdiana. 2014. Manajemen Operasi. Bandung: CV Pustaka Setia.

Utama, I Gusti Bagus Rai. 2014. Pengantar Industri Pariwisata. Yogyakarta: Deepublish. 